\title{
The Resource Effect of Political Connections
}

\author{
Zou Caifen 1, a, Ge Rong2,b ,Yu Qian ${ }^{3 . c}$ \\ 1,2,3Accounting School, Wuhan Textile University, Wuhan Hubei 430200 \\ a hicarol@163.com, b330819122@qq.com,b3037195008@qq.com
}

Key words: Political connections, Debt financing, Government subsidies, Tax preferences

Abstract: With the transformation and social structure of relationship-oriented in China, political connections widely exist in various. Each year many businesses spent huge amounts of time and money on establishing political connections. Taking GEM Listing Corporations as samples, This paper studied what kind of resources the political connection brought to the enterprise. The result found that political connections and debt financing have a significant positive correlation, and government subsidies have a significant negative correlation, and tax preferences have a significant negative correlation.

\section{Introduction}

The government builds the market order by formulating various economic policies and control measures, provides a lot of behavioral norms for business activities. The survival and development of enterprises need to be supported by many external scarce resources, such as tangible financial capital and intangible policy resources. Essentially the same as other behaviors of enterprises, the establishment of political connection in enterprises aims to maximize the benefits, hoping to obtain the resources available through this relational capital to influence governmental behavior.

The empirical evidence also shows that enterprises with political background can enjoy low financing $\operatorname{costs}^{[1,2]}$ and high rate of liability, it is more likely to receive assistance from local governments in financial difficulties ${ }^{[3]}$, easier access to long-term loans ${ }^{[4]}$. Companies can also use their political resources to help the company get out of trouble ${ }^{[5]}$, compared with the non-political connection enterprises. In addition to direct access to bank loans and access to capital markets and other financing advantages, companies with political connections can also get a variety of preferential policies, such as tax preferences and more government subsidies, getting various resources at a price below the market, more competitive in the market ${ }^{[6]}$, having the preferential qualifications access to market ${ }^{[7]}$. Political connections can mitigate the policy risks to protect enterprise income, and reduce the possible infringement suffered.

\section{Literature Review and Research Hypothesis}

\section{Political Connection and Financing}

Political connection has informative effect. External financing is an important factor affecting the development of enterprises. Political connection as a signal of enterprise business efficiency can reduce the business risks of private enterprises, avoid credit discrimination and pass the image of good prospect and social reputation to the public. Equivalent to an invisible government guarantees, political connection smoothes the degree of information asymmetry between capital supply and demand ${ }^{[7]}$, playing an important role in debt contracts with more favorable loan conditions and lower loan interest rates available ${ }^{[8]}$. Accordingly, we put forward the hypothesis 1 .

Hypothesis 1: Enterprise with political connection has a significant positive correlation with 
debt financing

\section{Political Connection and Government Subsidy}

Government financial subsidy is part of political and economic policy of the government in order to achieve a specific purpose. The communication between politically connected enterprises and government departments is more effective, more likely to obtain identification and approval of financial subsidies of the relevant government departments in the tournament for local government financial subsidies. Since there existed information asymmetry in the government's decision to provide subsidies to enterprises, such as enterprise production technology, product market, development potential, profit ability, employment opportunities created and potential tax capacity etc, political connection may be a kind of signal display mechanism with good development prospect and social reputation, may be considered to have good prospects for development and social contributions ${ }^{[9]}$. Political connection enhance the ability of enterprises to obtain resources, improve the profitability of the enterprises in the future, help enterprises get more government subsidies when they fall into financial difficulties. Accordingly, we put forward the hypothesis 2 .

Hypothesis 2: Enterprise with political connection has a significant positive correlation with government subsidies.

\section{Political Connection and Tax Preference}

Tax burden affects the enterprise value and development space. The level of the tax burden of enterprises not only relates to provisions of the tax system and policy, but also relates to the degree of implementation of the policy ${ }^{[10]}$. Political connection may have important impact on the tax burden of enterprises. The higher the administrative level of the actual controller or senior executives of the political-connect enterprises is, the more likely to obtain the identification and approval of preferential tax policy. The empirical evidence shows that tax rate of political connection enterprises is lower than those non-connected. Accordingly, we put forward the hypothesis 3.

Hypothesis 3: Enterprise with political connection has a significant positive correlation tax preferences

\section{Research Design}

\section{Sample and Data}

The sample of this paper is the GEM Listing Corporation of 2010-2012, after deleting missing data a total of 356 samples were obtained. The data comes from the CCER database. The corporate executives of political connected enterprises mainly are whether deputies, CPPCC members of theirs had worked in government departments.

\section{Description of Research Variables}

The variables and their calculation methods are shown in Table 1. 
Table 1 Variable symbols and calculation method

\begin{tabular}{|c|c|c|c|}
\hline & Variable & Symbol & Calculation Methods \\
\hline \multirow{3}{*}{$\begin{array}{l}\text { Dependent } \\
\text { Variable }\end{array}$} & Debt financing & Debt & Liabilities / Total assets \\
\hline & Government subsidies & Subsidy & Government subsidies / Total assets \\
\hline & Tax preferences & TaxCredit & Actual income tax rate, net profit / total profit \\
\hline $\begin{array}{c}\text { Independent } \\
\text { Variable }\end{array}$ & Political connection & Politic & $\begin{array}{l}\text { Dummy variables, } 1 \text { for a politically connected } \\
\text { enterprise, } 0 \text { for non political connection }\end{array}$ \\
\hline \multirow{7}{*}{$\begin{array}{l}\text { Control } \\
\text { Variable }\end{array}$} & $R \& D$ intensity & R\&D & R\&D expenditure / Total revenue \\
\hline & Innovation performance & Patent & Number of patents approved in the current period \\
\hline & $\begin{array}{l}\text { The proportion of the } \\
\text { largest shareholder }\end{array}$ & Shareholder & $\begin{array}{l}\text { The shares holding by first major shareholders / } \\
\text { the total number of shares. }\end{array}$ \\
\hline & Corporate size & Size & The logarithm of total assets \\
\hline & Profitability & ROA & Net profit / total assets \\
\hline & Location & Location & $\begin{array}{l}\text { Virtual variables, } 1 \text { is enterprises in the eastern } \\
\text { region, } 0 \text { is the central and Western Regions }\end{array}$ \\
\hline & Growth & Q & Tobin's Q, company market value / book value \\
\hline
\end{tabular}

\section{Research Model}

In order to test the hypothesis $1,2,3$, we constructed the model (1), (2), (3) to test.

Debt $=\alpha+\beta_{1}$ Poltic $+\beta_{2}$ R $\& D+\beta_{3}$ Patent $++\beta_{4}$ Shareholder $+\beta_{5}$ Size $+\beta_{6}$ Roa $+\beta_{7}$ Location $+\beta 8 Q+\varepsilon$

Subsidy $=\alpha+\beta 1$ Poltic $+\beta 2$ R $\& D+\beta 3$ Patent $++\beta 4$ Shareholder $+\beta 5$ Size $+\beta 6$ Roa $+\beta 7$ Location $+\beta 8 Q+\varepsilon$

TaxCredit $=\alpha+\beta 1$ Poltic $+\beta 2$ R $\& D+\beta 3$ Patent $++\beta 4$ Shareholder $+\beta 5$ Size $+\beta 6$ Roa $+\beta 7$ Location $+\beta 8 Q+\varepsilon$

\section{Regression Result}

\section{Descriptive Statistics Analysis}

Table 2 shows the descriptive statistics of the main variables. In 2010-2012, most of the GEM companies are non state-owned companies, at the same time, more than half of the enterprises have political connections. The maximum value of government subsidies is 0.0949 , the minimum value is 0 , and the mean value is 0.0093 . It shows that the government subsidy of listing Corporation in China is still at a low level. The maximum value of the tax preference is 0.3307 , mean value is 0.1433 which shows China's tax preference is relatively high. The maximum value of debt financing is $74.69 \%$, the minimum value is $1.26 \%$, and the mean value is $18.01 \%$ indicating that the level of corporate debt financing is relatively high.

Table 2 Descriptive Statistical Analysis

\begin{tabular}{|c|c|c|c|c|c|}
\hline & $\begin{array}{c}\text { Average } \\
\text { value }\end{array}$ & $\begin{array}{c}\text { Mid } \\
\text { value }\end{array}$ & $\begin{array}{c}\text { Maximum } \\
\text { value }\end{array}$ & $\begin{array}{c}\text { Minimum } \\
\text { value }\end{array}$ & $\begin{array}{c}\text { Standard } \\
\text { deviation }\end{array}$ \\
\hline Government Subsidies & 0.0093 & 0.0062 & 0.0949 & 0 & 0.0111 \\
\hline Tax Preferences & 0.1433 & 0.1441 & 0.3307 & 0 & 0.0485 \\
\hline Debt Financing & 0.1801 & 0.1369 & 0.7469 & 0.0126 & 0.137 \\
\hline Political Connection & 0.47 & 0 & 1 & 0 & 0.4996 \\
\hline R\&D Intensity & 0.0718 & 0.0464 & 0.9839 & 0.0008 & 0.0908 \\
\hline Innovation Performance & 11.2997 & 6 & 115 & 0 & 16.2334 \\
\hline Proportion of the Largest Shareholder & 0.3502 & 0.3332 & 0.855 & 0.0066 & 0.1317 \\
\hline Corporate Size & 19.6589 & 19.5705 & 22.3576 & 18.0036 & 0.6858 \\
\hline Profitability & 0.0761 & 0.0651 & 0.469 & -0.0008 & 0.049 \\
\hline Location & 0.772 & 1 & 1 & 0 & 0.42 \\
\hline Growth & 1.5155 & 1.4579 & 3.7156 & 0.0774 & 0.4983 \\
\hline
\end{tabular}

\section{Regression Analysis}

From the regression coefficient of Table 3, the political connection and the debt financing are 
positively related significantly which verifies the hypothesis 1 . The political connection and government subsidies are negatively related insignificantly, the result is inconsistent with the hypothesis 2 . The political connection and the tax preference are negatively related significantly which is inconsistent with the hypothesis 3.

Table 3 Regression analysis

\begin{tabular}{|c|c|c|c|}
\hline & Debt Financing & Government Subsidies & Tax Preferences \\
\hline \multirow{2}{*}{ Constant } & $-0.8308^{* * *}$ & $0.0512^{* * *}$ & -0.0259 \\
& $(0.0001)$ & $(0.0005)$ & $(0.6866)$ \\
\hline \multirow{2}{*}{ Political connection } & $0.0290^{* *}$ & -0.0009 & $-0.0069^{*}$ \\
& $(0.0205)$ & $(0.3308)$ & $(0.0787)$ \\
\hline \multirow{2}{*}{ R\&D intensity } & $-0.1261^{*}$ & $0.0151^{* * *}$ & $-0.1066^{* * *}$ \\
& $(0.0737)$ & $(0.0026)$ & $(0.0000)$ \\
\hline \multirow{2}{*}{ R\&D performance } & 0.0001 & $0.0001^{* * *}$ & 0.0000 \\
& $(0.8525)$ & $(0.0002)$ & $(0.8102)$ \\
\hline \multirow{2}{*}{ Proportion of the largest shareholder } & $0.1746^{* * *}$ & -0.0042 & $0.0309^{* *}$ \\
& $(0.0003)$ & $(0.2167)$ & $(0.0383)$ \\
\hline \multirow{2}{*}{ Corporate size } & $0.0542^{* * *}$ & $-0.0025^{* * *}$ & $0.0082^{* *}$ \\
& $(0.0000)$ & $(0.0006)$ & $(0.0107)$ \\
\hline \multirow{2}{*}{ Profitability } & $0.2038^{*}$ & $0.1237^{* * *}$ & $-0.0279^{* * *}$ \\
\hline \multirow{2}{*}{ Location } & $(0.0993)$ & $(0.0000)$ & $(0.4707)$ \\
\hline \multirow{2}{*}{ Growth } & $-0.0279^{*}$ & -0.0010 & -0.0007 \\
& $(0.0734)$ & $(0.3841)$ & $(0.8849)$ \\
\hline Adjusted $\mathrm{R}^{2}$ & $-0.0751^{* * *}$ & -0.0013 & 0.0039 \\
\hline F statistic & $(0.0000)$ & $(0.1453)$ & $(0.3160)$ \\
\hline The value of D-W & 0.2263 & 0.4179 & 0.1043 \\
\hline v & $14.7855^{* * *}$ & $34.7459^{* * *}$ & $6.4891^{* * *}$ \\
\hline & 1.4588 & 1.7766 & 1.7971 \\
\hline
\end{tabular}

Note: $* * * * *, *$ indicate significance at the level of $1 \%, 5 \%$ and $10 \%, \mathrm{P}$ value of the corresponding coefficients is in the bracket.

\section{Conclusions}

This study analyzed the resource effect of the political connection. The results showed that political connection has a significant positive correlation with debt financing, an insignificant negative correlation with government subsidies, and a significant negative correlation with tax preferences.

Therefore, the political connection does not necessarily bring the enterprise resource facility, may also bring a negative effect on the enterprise. The enterprises should focus on the development of core competitive advantage instead of taking opportunity by seeking rent.

\section{Acknowledgements}

This work was financially supported by the Humanities and Social Sciences Fund From Hubei Provincial Department of Education(No.15D059).

\section{References}

[1] A. Khwajia, A.Mian : submitted to Quarterly Journal of Economics(2005).

[2] S. Claessens, E. Feijend, and L.Laeven: submitted to Journal of Financial Economics(2008). 
[3] M. Faccio, R. W. Masulis, J. J. McConnell: submitted to Journal of Finance(2006).

[4] Deming Yang, Can Zhao: submitted to Auditing and Economic Research(2015),In Chinese.

[5] V.Dombrovsky. Information on http://papers. $\operatorname{ssm} . \operatorname{com}(2008)$.

[6] Faccio M: submitted to America Economic Review(2006).

[7] Wei Yu, Miao-jun Wang and Xiang-rong Jin: submitted to Economic Research(2012). In Chinese.

[8] L.Infante,M. Piazza. : submitted to Journal of Corporate Finance(2014).

[9] R.Cull, L. C.Xu : submitted to Journal of Financial Economics(2005).

[10] Danglun Luo, Yuping Yang : submitted to Journal of World Economy(2013). In Chinese. 